\title{
STUDY AND ANALYSIS OF LOW COST HOUSING BASED ON CONSTRUCTION TECHNIQUES
}

\author{
Dhiraj B Tapkir ${ }^{1}$, Nikhil R Mohire ${ }^{2}$, Pratik N Zurunge ${ }^{3}$, Siddharth R Sonsale ${ }^{4}$, A.W Dhawale ${ }^{5}$ \\ ${ }^{1,2,3,4}$ Students of J.S.P.M's Imperial College of Engineering and Research, Wagholi, Pune, India. \\ ${ }^{5}$ Project guide \& HOD Civil Engineering Department
}

\begin{abstract}
This paper addresses the approach to minimize the cost of house and it give affordability to the people now days .the basic principle behind this is to reduce cost of project by reducing duration of project and using different techniques which helps to reduce cost of project without losing quality. There are three factors which affect the cost of housing i.e. time, material used and techniques. The selection of building materials should meet the needs of local conditionsa field study was carried out in pune city, comparison is carried out with the help of persons such as engineers in mhada,jnnurm, housing who are involved in construction of low cost housing. For achieving the low cost, perfect technique is required in this paper the use of perfect techniques and comparison between different techniques is discussed for cost control and reduction.
\end{abstract}

Keywords: Low Cost Housing, Techniques, MHADA, JNNURM, Cost Efficient.

\section{INTRODUCTION}

Being one of the largest countries in the world and possessing one of the largest populations in the world India still has lots of areas where it is lagging behind in comparison with the topmost economies in the world.

As we know india has population about 1.4 billion and increasing at an unbelievable rates. Since the availability of the land is limited and demands for their accommodation and various other needs is increasing. India is developing country having about $30 \%$ of people of high income group and other are middle class and low income group, low cost houses constructed without sacrificing performance and life of structure.

Housing has associate degree importance to quality of life with considering economic, social, cultural and private significance. the main focus of this analysis is on housing for low financial gain households or what's usually called reasonable housing. reasonable housing may be a term wont to describe individuals whose total housing prices area unit deemed "affordable" to people who have a median financial gain. A median financial gain refers to the typical pay scale level of the bulk individuals in a very population that is commonly low. Low-income housing is aims at people while not enough financial gain to produce adequate housing for them and/or their families. These families area unit ometimes unable to get a home as a result of they fail to qualify for a mortgage. Most families choose to rent based on their income and family situation; unfortunately, there may not be enough rental housing or enough good-quality rental housing for lowincome families.

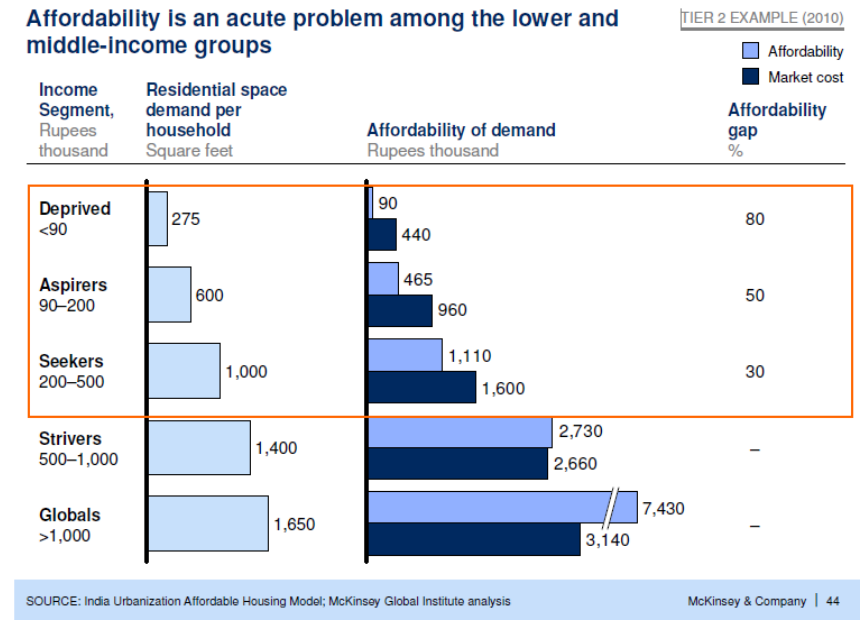

Fig 1: affordability and demand of house

Housing in India has been a great challenge. Millions of houses are required to build in a certain time frame. $99 \%$ of these houses are required by the Low income groups. If the time frame is not maintained the new slums will come up. In civil engineering works, thus, the structures are designed by keeping in mind all these factors related to low cost housing.this will lead to increase availability of shelter to people having low income group.

\section{OBJECTIVES}

House is one of the biggest need and low cost housing gives the houses to people at reasonable rate. Therefore, the main aim of this study is: 
1) To study different types of Construction technique used to reduce cost of housing

2) To Compare cost and time reduction by adopting different techniques for large scale project.

\section{SCOPE OF STUDY}

Present study deals with various techniques which help to reduce the cost of project. Analyzing the factors which increases the cost .This study is totally based on precast, aluform and conventional technique. The motive of this study is to control the cost by maintaining quality which is the biggest threat now days. The main motive behind that is to increase availability of house at reasonable rates and use of new, modern techniques which reduce the cost of project.

Overall this study will be very useful for the previous, ongoing, and upcoming future construction projects of high scale area to minimize the cost, time and waste and also the enhancement of structure.

\section{LITERATURE REVIEW}

\section{Vidya Devi,RinkiTaur (Oct 2009)}

This paper aims at varied aspects of prefab building methodologies for low value housing by lightness the various manufacture techniques to scale back the price of construction. Since there's continuous and recurrent production of same varieties of parts in formed construction, therefore, it ends up in quicker execution, a lot of productivity and economy. In prefab construction, the work on web site is reduced to minimum, thereby, enhancing the standard of labor, responsibleness and cleanliness.

\section{Jones Lang LaSalle (2011)}

The paper offers the concept concerning Urbanization and Housing shortage in Bharat as per EWS, LIG, MIG and HIG as per the technical cluster report on Estimation of Urban Housing .In this paper below the Policy Framework and rules for Low price Housing the Central level Schemes likewise as State sponsored initiatives area unit mentioned. Central level schemes like. statesman National renewal Mission (JNNURM) and Maharashtra Housing and space Development Authority (MHADA)

\section{SwaptikChowdhury, Sangeeta Roy (Jan21,2013)}

The paper grants work on inexpensive having blessings on areas such as Asian nation wherever concrete or steel is dear. This paper aims to means the varied aspects of prefab building ways for low price housing by light the various fabrication techniques, and therefore the efficient blessings achieved by its adoption which might be studied one by one supported the requirements so, rising the speed of construction and reducing the development price. the foremost gift ways of construction systems thought of here square measure particularly, structural, precast.

\section{RESEARCH METHODOLOGY}

The methodology adopted for gift study is completing survey of enormous scale comes. elaborated study of 3 completely different techniques like standard, formed and aluform is dispensed by analyzing price needed for specific methodology and so comparison it with relevance price and time needed . This study is predicated on works and field survey.

The study target sorting out problems caused from low price house extension comes that have an effect on the development activities. the sector study is split into 3 components - On web site observation on construction activities to examine and observe construction activities dispensed by the contractors. Finding new construction techniques to implement them in construction of building. Study of low price construction materials from comes underneath construction and recently completed. once completion of those processes, web site observations are dispensed to assemble main knowledge

\section{RESULTS AND DISCUSSION}

Analysis is done on three site data :

Site 1- MHADA PROJECT, Morwadi, Pimpri. (Pre-cast) Site 2- JNNURM Project, Vetalnagar. (Aluform) Site3- Row House Project, Sathewasti, Vishrantwadi (Conventional)

This information is useful to see the analysis starting and direction. Reviews of different works from literature survey can become the backbone of this analysis. Comparison of low price building with typical building.

Time Reduction:

\begin{tabular}{|l|l|l|l|}
\hline Sr. No & $\begin{array}{l}\text { Conventional } \\
\text { Method }\end{array}$ & $\begin{array}{l}\text { Pre-Cast } \\
\text { Method }\end{array}$ & $\begin{array}{l}\text { Aluform } \\
\text { Method }\end{array}$ \\
\hline 1 & - & $33.33 \%$ & $58.33 \%$ \\
\hline
\end{tabular}

Cost Reduction:

\begin{tabular}{|l|l|l|l|}
\hline Sr. No & Conventional & Pre-cast & Aluform \\
\hline 1 & - & $21.93 \%$ & $19.84 \%$ \\
\hline
\end{tabular}

\section{CONCLUSION}

From above study we conclude that,

1. Their is Cost reduction in construction due to adaptation of different (Pre-cast, Aluform) technique.

2. Aluform is Best construction Technique in which Construction Cost reduction is $32.28 \%$ and Time reduction is $58.33 \%$ more and waste production also very less.

3. Pre-cast gives strength to the structure and cost is less than conventional but more than aluformtechnique,Time required also less than conventional technique but more than aluform technique. 
4. For Cost effective houses present study clearly states that aluform technique is suitable technique for low cost housing mega projects.

\section{REFERENCES}

[1].Jones Lang LaSalle(2011); study of low cost housing in india and its need.

[2].Swaptik Chowdhury, Sangeeta Roy School of Mechanical and Building Sciences, VIT University, Vellore, India.

[3].Kumar A (1999).Sustainable building technology for mass application, Development Alternatives Newsletter. 9(11), pp. $1-4$.

[4].Tiwari P, Parikh K and Parikh J (1999). Structural design considerations in house builder construction model: a multiobjective optimization technique, Journal of Infrastructure System. 5(3), pp. 75-90

[5].Works Department (2002). Revised schedules of rates 2000 works department and analysis of rates, Works Department, India

[6].TERI. 2007. Policy, institutional and legal barriers to economic utilization of fly ash. New Delhi: The Energy and Resources Institute. $151 \mathrm{pp}$.

[7].Garg R.K., 'Sustainable Human Settlements and Cost Effective Housing Technologies

[8].(2001-2002) Sunil KumarDepartment of Civil Engineering, Harcourt Butler Technological Institute, Kanpur 208002, India Received 17 April 2001; received in revised form 22 April 2002; accepted 31 May 2002

[9].Vivian W. Y.The Twelfth East Asia-Pacific Conference on Structural Engineering and Construction "Cost Effectiveness of using Low Cost Housing Technologies in Construction" Tam1*1 School of Engineering, University of Western Sydney.

[10]. Javed sultan, president kinkoo.inc, Cambridge MA 02139, USA 